\title{
Thymus and activation-regulated chemokine (TARC)/CCL17 and lgE are associated with elderly asthmatics
}

Kyung Mi Jo ${ }^{1+}{ }^{\text {, Hyo Kyung Lim }}{ }^{2 \dagger}$, Jae Woong Sull ${ }^{1,3}$, Eugene Choi ${ }^{4}$, Ji-Sook Lee ${ }^{5}$, Mee Ae Cheong ${ }^{1}$, Min Hwa Hong ${ }^{1}$, Yoori Kim ${ }^{1}$ and In Sik Kim ${ }^{1,2^{*}}$

\begin{abstract}
Background: The pathogenesis of asthma, which is an allergic lung disease, is associated with a variety of allergens such as house dust mite, pollen, and mould, IgE containing serum IgE and allergen-specific-lgE, and inflammatory cytokines including thymus and activation-regulated chemokine (TARC)/CCL17. Because aging is an essential factor in the pathogenesis of asthma, we examined biomarkers related to asthmatic subjects depending on age.

Results: Physiological indices such as FEV1(forced expiratory capacity in 1 s), FEV1 (\% predicted), and FEV1/ FVC(forced vital capacity) (\%) in asthmatic subjects were lower than those in normal subjects. Total IgE, Der p1 specific IgE, and Der f1 specific lgE were elevated in serum of asthmatics relative to normal individuals. Regulated on activation, normal T cell expressed and secreted (RANTES)/CCL5 in serum and interleukin 6 (IL-6), interleukin 8 (IL-8), monocyte chemoattractant protein (MCP)-1/CCL2, RANTES, and macrophage inflammatory protein (MIP)-1a/ CCL3 in bronchoalveolar lavage fluid (BALF) of asthmatic subjects were higher than in normal individuals. Upon classification of experimental groups depending on age, physiological indices and Der p1-specific lgE (class) were decreased in middle aged adult and elderly adult groups relative to the young adult group. TARC levels in serum were strongly elevated in the elderly adult group relative to the young adult and the middle aged adult groups. TARC in serum was related to total IgE in serum in the elderly adult group.

Conclusions: Taken together, although TARC in serum and BALF is not different between normal and asthmatic individuals, TARC increases in serum of elderly asthmatic subjects. The level of TARC has a positive effect on the level of IgE in the elderly adult group. These findings may help us better understand the relationship of pathogenesis of allergic diseases and aging.
\end{abstract}

Keywords: Asthma, Aging, TARC, Allergen-specific lgE

\section{Background}

Asthma is an allergic disease in the respiratory tract that is characterized by lung inflammation and mucus secretion resulting in airway obstruction, as well as allergenspecific IgE [1, 2]. Asthma is caused by a variety of elements including environmental, genetic and immunological factors. House dust mites (HDMs), including

\footnotetext{
* Correspondence: orientree@eulji.ac.kr

${ }^{\dagger}$ Equal contributors

'Department of Senior Healthcare, BK21 plus program, Graduate School, Eulji University, Daejeon 34824, Korea

${ }^{2}$ Department of Biomedical Laboratory Science, School of Medicine, Eulji University, 77, Gyeryoung-ro 771 beon-gil, Jung-Gu, Daejeon 34824, Republic of Korea Full list of author information is available at the end of the article
}

Dermatophagoides pteronissinus (DP) and Dermatophagoides farinae (DF), may be sources of many specific allergen proteins including Der p 1 and Der f $1[3,4]$. More than half of asthmatics are sensitized to HDM and have elevated levels of HDM-specific IgE in their serum. Cytokine secretion, which is one of the most important allergic inflammatory responses, is increased by HDM via Toll-like receptor (TLR) and proteinase-activated receptor (PAR) [5, 6]. Cytokines including interleukin 4 (IL-4), interleukin 5 (IL-5), IL-6, IL-8, interleukin 10 (IL-10), monocyte chemoattractant protein (MCP)-1/CCL2, and thymus and activation-regulated chemokine (TARC)/

(c) The Author(s). 2018 Open Access This article is distributed under the terms of the Creative Commons Attribution 4.0 International License (http://creativecommons.org/licenses/by/4.0/), which permits unrestricted use, distribution, and 
CCL17 trigger secondary inflammatory events, aggravating asthma pathogenesis.

Aging is an unavoidable and complicated process characterized by progressive loss of functional activity, repair, and recovery. Interaction of the proinflammatory state with aging, which is very important, occurs via the inflamm-aging process $[7,8]$. Aging studies have suggested that potential biomarkers containing proinflammatory cytokines, hypoxic indicators, and redox state may be related to inflammation-associated aging. Asthma in elderly subjects shows higher mortality than in younger members of the population, including children and younger adults, and is underdiagnosed by agerelated alterations such as dyspnea, immunosenescence and decreased skin test sensitivity [9]. Although asthma in elderly subjects is associated with immunological and non-immunologic mechanisms, the exact interaction of aging and asthma has yet to be unveiled. In this study, we divided subjects into young adults, middle-aged adults, and elderly adults and studied the association of asthma and aging with biomarkers including cytokine and HDM-specific IgE in serum.

\section{Methods}

\section{Study population}

A total of 121 asthmatic subjects were randomly recruited from Konyang University Hospital according to the global initiative for asthma (GINA) guideline. The asthmatic subjects were classified as young adults (10-39 years), middle-aged adults (40-59 years), and elderly adults ( $\geq$ 60 years). Subjects were excluded if they had no history of smoking and other comorbidities. Additionally, 106 normal subjects were recruited as controls. The normal subjects had normal lung function, no history of asthma, and did not require medication.

\section{Collection of serum and BALF}

Blood samples were collected and then centrifuged, after which the supernatant was separated from the samples. Following local anesthesia with lignocaine, sterile phosphate-buffered saline (PBS) $(5 \times 20 \mathrm{~mL})$ was administered to lungs of normal $(n=9)$ and asthmatic $(n=39)$ individuals, after which the fluid was gently aspirated, pooled and collected into a tube. Nucleated cells in BALF and blood were counted using a Neubauer hemocytometer. Differential cell counts were performed from cytospin slides. Serum and BALF were stored at $70{ }^{\circ} \mathrm{C}$ until used in this experiment.

\section{Laboratory investigations}

White blood cell differential counts, hemoglobin and hematocrit levels were determined directly using a Sysmex XE-5000 system (Sysmex Corporation, Kobe, Japan). For measurement of serum HDM-specific IgE, serum was loaded into a Pharmacia Unicap 100 system (Pharmacia Unicap, Uppsala, Sweden). The DP or DF allergen covalently coupled to the cellulose solid-phase ImmunoCap and reacted with the specific IgE in the patient's serum specimen. After washing, enzyme-labeled antibodies against IgE were added to form a complex, after which the IgE concentration was measured by fluorescence. HDM (DP or/and DF)-specific IgE + is defined as $>0.35 \mathrm{kU} / \mathrm{L}$; class $0,<0.35 \mathrm{kUA} / \mathrm{L}$; class $1,0.35$ - $<0.7 \mathrm{kUA} / \mathrm{L}$; class 2, $0.70-<3.5 \mathrm{kUA} / \mathrm{L}$; class $3,3.50$ - $<17.5 \mathrm{kUA} / \mathrm{L}$; class 4, $17.5-<50 \mathrm{kUA} / \mathrm{L}$; class 5, 50 - $\leq 100 \mathrm{kUA} / \mathrm{L}$; and class 6, > $100 \mathrm{kUA} / \mathrm{L}$. Pulmonary function tests such as FEV1, FEV1 (\% predicted), FVC, and FEV1/FVC were measured to determine the state of lung obstruction.

\section{Measurement of cytokine and chemokine concentrations}

Concentrations of IL-4, IL-5, IL-6, IL-8, IL-10, MCP-1, tumor necrosis factor (TNF)- $\alpha$, interferon (IFN)- $\gamma$, granulocyte macrophage colony simulation factor (GM-CSF), TARC, RANTES, and MIP- $1 \alpha$ in serum were measured with a sandwich enzyme-linked immunosorbent assay (ELISA) using a cytokine measurement kit (BD Biosciences, San Diego, CA, USA; R\&D Systems, Minneapolis, MN, USA) according to the manufacturer's instructions. Briefly, 96-well plates were coated with $100 \mu \mathrm{L} /$ well of appropriate monoclonal antibodies in $0.1 \mathrm{M}$ carbonate buffer and incubated overnight at $4{ }^{\circ} \mathrm{C}$, after which the plates were washed with PBS solution containing 0.05\% Tween-20 and blocked with PBS solution with $5 \%$ bovine serum albumin (BSA) for $30 \mathrm{~min}$ at room temperature. Next, serum was added to the plates and incubated for $2 \mathrm{~h}$ at room temperature. The plates were then washed three times, after which they were incubated with appropriate secondary antibodies for $2 \mathrm{~h}$ at room temperature. The plates were then washed three times and incubated with substrate solution. Finally, the reaction was blocked by adding stop buffer and the absorbance was read at $450 \mathrm{~nm}$.

\section{Statistical analysis}

Data were presented as the means \pm S.E.M. Statistical differences were analyzed using a Student's t test for two-group comparisons. ANOVA was used to compare the three investigated age groups. Multiple comparisons were performed with Tukey's post-hoc test. The Pearson correlation coefficient $(R)$ was applied to present the strength of the relationship between variables. All analyses were conducted using the SPSS statistical software package (Version 20.0, Chicago, IL), with a $p<0.05$ considered to be statistically significant. 


\section{Results}

\section{Characteristics of the study population}

Physiology indices such as FEV1, FEV1 (\% predicted) and FEV1/FVC in asthmatic subjects were decreased relative to normal subjects. Eosinophils in blood and BALF were increased in asthmatic subjects relative to normal subjects. Total IgE, Der p1-specific IgE and Der f1-specific IgE were increased in serum of asthmatic subjects relative to normal subjects (Table 1). Although Der p1-specific IgE (class) and Der f1-specific IgE (class) increased in the asthmatic group, the values did not differ significantly from those of the normal group. The level of MCP-1 and RANTES in serum and of IL-6, IL-8, MCP-1, RANTES and MIP- $1 \alpha$ in BALF were significantly increased in the asthmatics relative to the normal subjects (Table 2).

Moreover, MIP- $1 \alpha$ in serum of the asthmatic group was lower than in normal. Cytokines did not differ in serum and BALF between atopic and non-atopic asthmatic groups (Additional file 1: Table S1).
Different expression of measured parameters among normal and asthmatic age groups

The population of normal and asthmatic subjects was divided into three age groups, young adults (10-39 years), middle-aged adults (40-59 years) and elderly adults (60-83 years). Hb, Hct, ESR, Der p 1-specific IgE, and TARC were not significantly altered among three groups of normal (Additional file 1: Table S2). In asthmatic group, $\mathrm{Hb}$ and Hct were decreased in the elderly adult group, but ESR was increased in the elderly adult group relative to the young adult group. Indices such as FVC, FEV1 and FEV1/FVC were decreased in the elderly adult group relative to the young adult and middleaged adult groups. The level of Der p1 IgE(class) in the middle-aged adult and elderly adult groups decreased significantly when compared to the young adult group. The level of serum TARC was markedly elevated in the elderly adult group relative to the young adult and the middle-aged adult groups (Table 3). The difference of TARC in each group between normal and asthmatic subjects is not significant (Additional file 1: Table S2).

Table 1 Characteristics of the study population

\begin{tabular}{|c|c|c|c|}
\hline \multirow{2}{*}{\multicolumn{2}{|c|}{$\overline{\text { Number of subjects (female/male) }}$}} & Normal & Asthma \\
\hline & & $106(62 / 44)$ & $121(66 / 55)$ \\
\hline \multicolumn{2}{|c|}{ Age (years) } & $45.3 \pm 12.7(19 \sim 72)$ & $50.8 \pm 16.7(15 \sim 84)$ \\
\hline \multicolumn{2}{|l|}{$\mathrm{FEV} 1^{\S}$} & $4.1 \pm 0.9(2.7 \sim 5.3)^{* *}$ & $2.1 \pm 0.8(1 \sim 4)^{* *}$ \\
\hline \multicolumn{2}{|c|}{$\mathrm{FEV}^{\S}$ (\% predicted) } & $101.6 \pm 11.9(87.1 \sim 121.3)^{*}$ & $81.4 \pm 22.2(34 \sim 125)^{*}$ \\
\hline \multicolumn{2}{|c|}{ FVC" (\% predicted) } & $95.2 \pm 11.5(77.9 \sim 112.9)$ & $91.3 \pm 17.8(40 \sim 140)$ \\
\hline \multicolumn{2}{|c|}{ FEV1/FVC (\%) } & $91.6 \pm 4.9(84.8 \sim 97.9)^{* *}$ & $71.9 \pm 14.2(35 \sim 98)^{* *}$ \\
\hline \multirow[t]{5}{*}{ Blood cells } & Neutrophils & $55.3 \pm 9.7(28.5 \sim 75.4)$ & $59.5 \pm 14.3(27 \sim 92)$ \\
\hline & Lymphocytes & $35.7 \pm 9.3(20 \sim 67.3)^{* *}$ & $26.8 \pm 11.0(4 \sim 52)^{* *}$ \\
\hline & Monocytes & $6.7 \pm 3.2(2.0 \sim 19.0)^{* *}$ & $7.0 \pm 2.7(1 \sim 17)^{* *}$ \\
\hline & Eosinophils & $2.0 \pm 1.4(0 \sim 6.0)^{* *}$ & $5.7 \pm 8.4(0 \sim 55)^{* *}$ \\
\hline & Basophils & $0.3 \pm 0.3(0 \sim 1.3)^{*}$ & $0.5 \pm 0.5(0 \sim 4)^{*}$ \\
\hline \multirow[t]{8}{*}{ BALF cells } & Neutrophils & $2.0 \pm 1.6(0 \sim 5.1)^{* *}$ & $16.6 \pm 26.7(0 \sim 90)^{* *}$ \\
\hline & Lymphocytes & $10.6 \pm 8.4(1.0 \sim 29.2)$ & $16.9 \pm 17.0(0 \sim 69)$ \\
\hline & Macrophage & $86.2 \pm 10.4(62.0 \sim 99.0)^{* *}$ & $59.9 \pm 27.8(3 \sim 95)^{* *}$ \\
\hline & Eosinophils & $0.2 \pm 0.6(0 \sim 1.9)$ & $3.9 \pm 8.5(0 \sim 52)$ \\
\hline & Basophils & $0 \pm 0(0 \sim 0)$ & $0.04 \pm 0.1(0 \sim 1)$ \\
\hline & Epithelial cells & $0.8 \pm 1.0(0 \sim 2.5)$ & $2.38 \pm 9.6(0 \sim 86)$ \\
\hline & Total lgE & $92.8 \pm 143.4(2.2 \sim 694.2)^{* *}$ & $376.4 \pm 612.2(2 \sim 3000)^{* *}$ \\
\hline & Der p 1-specific lgE & $0.8 \pm 2.1(0 \sim 10.4)^{*}$ & $4.1 \pm 15.3(0 \sim 100)^{*}$ \\
\hline \multirow[t]{3}{*}{$\lg E$} & Der p 1-specific lgE (class) & $0.4 \pm 1.0(0 \sim 3)$ & $0.62 \pm 1.2(0 \sim 5)$ \\
\hline & Der f 1-specific lgE & $1.5 \pm 4.4(0 \sim 23.4)^{* *}$ & $7.3 \pm 19.5(0 \sim 100)^{* *}$ \\
\hline & Der f 1-specific lgE (class) & $0.8 \pm 1.2(0 \sim 4)$ & $1.2 \pm 1.5(0 \sim 5)$ \\
\hline
\end{tabular}

$\mathrm{FEV} 1^{\text {s }}$ : forced expiratory volume in 1 second

FVC": forced vital capacity

Data are expressed as the means \pm SD (the lowest value $\sim$ the highest value)

${ }^{*} p<0.05$ and ${ }^{* *} p<0.01$ indicate statistically significant differences between the normal and asthma groups 
Table 2 Measurement of cytokine concentration of the study population

\begin{tabular}{|c|c|c|c|}
\hline & & Normal & Asthma \\
\hline \multirow[t]{12}{*}{ Serum } & IL-4 & $297.3 \pm 1185.1(0 \sim 7126.6)$ & $342.0 \pm 831.7(0 \sim 4955)$ \\
\hline & IL-5 & $136.2 \pm 526.9(0 \sim 2744.7)$ & $189.7 \pm 1184.7(0 \sim 7399)$ \\
\hline & IL-6 & $6.2 \pm 22.2(0 \sim 134.4)$ & $11.0 \pm 12.2(0 \sim 50)$ \\
\hline & IL-8 & $46.2 \pm 234.8(0 \sim 1460.9)$ & $64.5 \pm 155.5(0 \sim 805)$ \\
\hline & IL-10 & $29.9 \pm 124.0(0 \sim 723.2)$ & $16.9 \pm 77.6(0 \sim 435)$ \\
\hline & MCP-1 & $466.9 \pm 860.4(8.9 \sim 3032.4)^{* *}$ & $2042.1 \pm 1427.3(246.9 \sim 8180.4)^{* *}$ \\
\hline & TNF-a & $87.2 \pm 135.1(8.5 \sim 884.3)^{* *}$ & $9.5 \pm 8.4(0 \sim 38)^{* *}$ \\
\hline & INF- $\gamma$ & $48.6 \pm 161.8(0 \sim 945.1)$ & $52.6 \pm 146.7(0 \sim 741)$ \\
\hline & GM-CSF & $31.1 \pm 36.6(13.1 \sim 185.1)$ & $32.1 \pm 5.1(27.1 \sim 55.7)$ \\
\hline & TARC & $9.0 \pm 23.9(0 \sim 150.3)$ & $4.9 \pm 15.8(0 \sim 64.7)$ \\
\hline & RANTES & $685.3 \pm 56.6(601.4 \sim 857.7)^{* *}$ & $800.4 \pm 98.0(553.7 \sim 978.7)^{* *}$ \\
\hline & MIP-1a & $81.2 \pm 91.5(11.0 \sim 338.2)^{* *}$ & $25.2 \pm 43.7(0 \sim 202.4)^{* *}$ \\
\hline \multirow[t]{12}{*}{ BALF } & IL-4 & $26.8 \pm 54.5(0 \sim 144)$ & $102.0 \pm 191.2(0 \sim 740)$ \\
\hline & IL-5 & $0.0 \pm 0.0(0 \sim 0)$ & $0.0 \pm 0.0(0 \sim 0)$ \\
\hline & IL-6 & $1.7 \pm 3.3(0 \sim 8)^{*}$ & $11.2 \pm 23.8(0 \sim 89)^{*}$ \\
\hline & IL-8 & $470.9 \pm 626.1(0 \sim 2041)^{* *}$ & $2682.1 \pm 4417.5(0 \sim 21,246)^{* *}$ \\
\hline & $\| \mathrm{L}-10$ & $0.0 \pm 0.0(0 \sim 0)$ & $0.0 \pm 0.0(0 \sim 0)$ \\
\hline & MCP-1 & $197.7 \pm 265.7(0 \sim 701)^{* *}$ & $936.7 \pm 1268.5(0 \sim 4452)^{* *}$ \\
\hline & TNF-a & $0.0 \pm 0.0(0 \sim 0)$ & $0.0 \pm 0.0(0 \sim 0)$ \\
\hline & INF- $\gamma$ & $9.0 \pm 14.6(0 \sim 39)$ & $11.6 \pm 15.6(0 \sim 59)$ \\
\hline & GM-CSF & $0.0 \pm 0.0(0 \sim 0)$ & $0.0 \pm 0.0(0 \sim 0)$ \\
\hline & TARC & $0.0 \pm 0.0(0 \sim 0)$ & $2.7 \pm 12.7(0 \sim 73.1)$ \\
\hline & RANTES & $0.0 \pm 0.0(0 \sim 0)^{* *}$ & $23.8 \pm 40.1(0 \sim 142.8)^{* *}$ \\
\hline & MIP-1a & $0.0 \pm 0.0(0 \sim 0)^{* *}$ & $50.7 \pm 84.9(0 \sim 376.0)^{* *}$ \\
\hline
\end{tabular}

\section{Correlation among measured parameters in the total} group and the elderly adult group of asthmatic subjects The correlations among measured parameters in the total and the elderly adult groups are shown in Table 4. The serum TARC showed a positive correlation with total IgE in asthmatic subjects and the elderly adult group based on Pearson's correlation coefficients. $(0.3<r<0.7)$. Serum IL-6 showed a negative correlation with Der p1 specific IgE (class) in the total asthmatic group based on Pearson's correlation coefficients $(-0.7<$ $r<-0.3)$. However, serum IL-6 was not significantly correlated with Der p1 IgE(class) in the elderly adult group.

Table 3 Different expression of the measured parameters among the asthmatic age groups

\begin{tabular}{|c|c|c|c|c|}
\hline & $\begin{array}{l}\text { Young adult group } \\
(N=33 \text {,Ave } 29.4 \pm 6.7)\end{array}$ & $\begin{array}{l}\text { Middle-aged adult group } \\
(N=49 \text {,Ave } 50.1 \pm 5.5)\end{array}$ & $\begin{array}{l}\text { Elderly adult group } \\
(\mathrm{N}=39, \text { Ave } 69.8 \pm 5.9) .\end{array}$ & $\begin{array}{l}P \text { value } \\
\text { (Tukey HSD) }\end{array}$ \\
\hline $\mathrm{Hb}$ & $13.9 \pm 2.0^{\$ \$}$ & $13.6 \pm 1.3$ & $12.8 \pm 1.3^{\$ \$}$ & 0.007 \\
\hline Hct & $41.2 \pm 5.7^{\$}$ & $40.1 \pm 3.9$ & $38.1 \pm 4.0^{\$}$ & 0.012 \\
\hline ESR & $17.8 \pm 17.3^{\$}$ & $23.2 \pm 24.3$ & $34.7 \pm 28.3^{\$}$ & 0.036 \\
\hline Der p1-specific lgE(class) & $1.12 \pm 1.4^{* \$}$ & $0.4 \pm 1.1^{*}$ & $0.43 \pm 1.1^{\$}$ & $0.042,0.050$ \\
\hline FVC & $3.6 \pm 1.0^{* * \$ \$}$ & $2.9 \pm 0.7^{* *}$ & $2.4 \pm 0.7^{\$ \$}$ & $\$ 0.000,{ }^{*} 0.001$ \\
\hline FEV1 & $3.0 \pm 0.7^{* * \$}$ & $2.1 \pm 0.6^{* * \# \#}$ & $1.5 \pm 0.5^{5 \text { 今\#\# }}$ & ${ }^{\$} 0.000,{ }^{*} 0.000,{ }^{\#} 0.001$ \\
\hline FEV1/FVC & $80.0 \pm 9.6^{\$ \$}$ & $73.2 \pm 13.1^{\# \#}$ & $63.6 \pm 14.8^{\text {\$\#\# }}$ & $\$ 0.000,{ }^{\#} 0.004$ \\
\hline Serum TARC & $0.0 \pm 0.0$ & $0.0 \pm 0.0^{\#}$ & $12.9 \pm 23.9^{\#}$ & \#0.045 \\
\hline
\end{tabular}

Data are expressed as the means \pm SD

${ }^{*} p<0.05$ and ${ }^{* *} p<0.01$ indicate between the young adult group and middle-aged group

$\# p<0.05$ and ${ }^{\# \#} p<0.01$ indicate between the middle aged group and elderly group

$\$ p<0.05$ and ${ }^{\$ \$} p<0.01$ indicate between the young adult group and elderly group 
Table 4 Correlation among the measured parameters in the total group and the elderly adult group of asthmatic subjects

\begin{tabular}{|c|c|c|c|c|c|c|}
\hline Total group & $\mathrm{pb}$ & $\mathrm{Hct}$ & ESR & FEV1/ FVC & Serum IL-6 & Serum TARC \\
\hline Total lgE & $\begin{array}{l}R=0.282 \\
p=0.004^{* *}\end{array}$ & $\begin{array}{l}R=0.294 \\
p=0.004^{* *}\end{array}$ & $\begin{array}{l}R=-0.232 \\
p=0.050^{*}\end{array}$ & $\begin{array}{l}R=0.049 \\
p=0.653\end{array}$ & $\begin{array}{l}R=-0.297 \\
p=0.111\end{array}$ & $\begin{array}{l}R=0.417 \\
p=0.022^{*}\end{array}$ \\
\hline Der p1-specific gE & $\begin{array}{l}R=-0.082 \\
p=0.388\end{array}$ & $\begin{array}{l}R=-0.099 \\
p=0.298\end{array}$ & $\begin{array}{l}R=0.047 \\
p=0.667\end{array}$ & $\begin{array}{l}R=-0.036 \\
p=0.713\end{array}$ & $\begin{array}{l}R=-0.223 \\
p=0.173\end{array}$ & $\begin{array}{l}R=-0.098 \\
p=0.553\end{array}$ \\
\hline Der p1-specific lgE(class) & $\begin{array}{l}R=-0.032 \\
p=0.734\end{array}$ & $\begin{array}{l}R=-0.049 \\
p=0.611\end{array}$ & $\begin{array}{l}R=-0.009 \\
p=0.932\end{array}$ & $\begin{array}{l}R=0.014 \\
p=0.884\end{array}$ & $\begin{array}{l}R=-0.344 \\
p=0.032^{*}\end{array}$ & $\begin{array}{l}R=-0.106 \\
p=0.519\end{array}$ \\
\hline Der f1-specific lgE & $\begin{array}{l}R=-0.041 \\
P=0.670\end{array}$ & $\begin{array}{l}R=-0.058 \\
p=0.546\end{array}$ & $\begin{array}{l}R=0.013 \\
p=0.905\end{array}$ & $\begin{array}{l}R=-0.048 \\
p=0.631\end{array}$ & $\begin{array}{l}R=-0.218 \\
p=0.182\end{array}$ & $\begin{array}{l}R=-0.099 \\
p=0.550\end{array}$ \\
\hline Der f1-specific lgE(class) & $\begin{array}{l}R=0.033 \\
p=0.733\end{array}$ & $\begin{array}{l}R=0.030 \\
p=0.755\end{array}$ & $\begin{array}{l}R=-0.114 \\
p=0.295\end{array}$ & $\begin{array}{l}R=-0.015 \\
P=0.876\end{array}$ & $\begin{array}{l}R=-0.160 \\
p=0.332\end{array}$ & $\begin{array}{l}R=-0.042 \\
p=0.799\end{array}$ \\
\hline Elderly adult group & $\mathrm{Hb}$ & $\mathrm{Hct}$ & ESR & $\begin{array}{l}\text { FEV1/ } \\
\text { FVC }\end{array}$ & S-IL-6 & S-TARC \\
\hline Total lgE & $\begin{array}{l}R=0.219 \\
p=0.229\end{array}$ & $\begin{array}{l}R=0.176 \\
p=0.336\end{array}$ & $\begin{array}{l}R=-0.370 \\
p=0.069\end{array}$ & $\begin{array}{l}R=0.223 \\
p=0.246\end{array}$ & $\begin{array}{l}R=-0.442 \\
p=0.173\end{array}$ & $\begin{array}{l}R=0.630 \\
p=0.038^{*}\end{array}$ \\
\hline Der p1-specific lgE & $\begin{array}{l}R=-0.090 \\
P=0.612\end{array}$ & $\begin{array}{l}R=-0.119 \\
P=0.501\end{array}$ & $\begin{array}{l}R=0.066 \\
p=0.743\end{array}$ & $\begin{array}{l}R=0.143 \\
p=0.443\end{array}$ & $\begin{array}{l}R=-0.073 \\
p=0.797\end{array}$ & $\begin{array}{l}R=-0.006 \\
P=0.982\end{array}$ \\
\hline Der p1-specific lgE(class) & $\begin{array}{l}R=0.128 \\
P=0.472\end{array}$ & $\begin{array}{l}R=0.094 \\
p=0.597\end{array}$ & $\begin{array}{l}R=0.049 \\
p=0.808\end{array}$ & $\begin{array}{l}R=0.185 \\
p=0.318\end{array}$ & $\begin{array}{l}R=-0.304 \\
P=0.271\end{array}$ & $\begin{array}{l}R=0.186 \\
p=0.507\end{array}$ \\
\hline Der f1-specific lgE & $\begin{array}{l}R=0.050 \\
P=0.780\end{array}$ & $\begin{array}{l}R=0.034 \\
p=0.849\end{array}$ & $\begin{array}{l}R=0.021 \\
p=0.917\end{array}$ & $\begin{array}{l}R=0.272 \\
p=0.139\end{array}$ & $\begin{array}{l}R=0.034 \\
p=0.906\end{array}$ & $\begin{array}{l}R=-0.052 \\
p=0.853\end{array}$ \\
\hline Der f1-specific lgE(class) & $\begin{array}{l}R=0.083 \\
p=0.643\end{array}$ & $\begin{array}{l}R=0.076 \\
p=0.668\end{array}$ & $\begin{array}{l}R=-0.280 \\
p=0.157\end{array}$ & $\begin{array}{l}R=0.377 \\
p=0.037^{*}\end{array}$ & $\begin{array}{l}R=-0.287 \\
p=0.300\end{array}$ & $\begin{array}{l}R=0.086 \\
p=0.760\end{array}$ \\
\hline
\end{tabular}

"correlation with $p<0.05$

*** correlation with $p<0.01$

\section{Discussion}

Asthma, which is one of the most prevalent allergic diseases, is caused by a variety of pathophysiological mechanisms [10]. HDMs are a major source of allergic asthma and DP and DF are of the most common HDMs [11]. IgE is considered a clear sign of allergic disease including asthma [11]. Der p 1 and Der f 1, major allergens proteins of HDMs, have a high IgE reactivity [12], and total IgE and Der p 1- or Der f 1-specific IgE are elevated in asthma [13]. In our study, total IgE, Der p1specific IgE, and Der f1-specific IgE were elevated in asthmatic subjects when compared to normal subjects (Table 1). In a previous study, asthmatic subjects showed significantly more eosinophils, neutrophils, and cytokines such as IL-5, IL-6, IL-8, granulocyte colony stimulation factor (G-CSF) and RANTES in BALF when compared to healthy control subjects $[14,15]$. As shown in Tables 1 and 2, neutrophils, IL-6, IL-8, RANTES, MCP-1, and MIP- $1 \alpha$ in BALF of asthmatic subjects were also elevated relative to normal subjects. Both IL-8 and RANTES are major factors in increasing migration and proliferation of neutrophils and bronchial smooth muscle cells. These cytokines may be involved in increases in immune cells, particularly neutrophils. Although we also measured IL-5 and GM-CSF in BALF and serum. The difference between normal and asthmatic subjects was not significant.
Aging is an unavoidable and complicated process characterized by progressive loss of functional activity, repair and recovery [16]. As shown in Table 2, hematological indices such as $\mathrm{Hb}$ and Hct in the elderly adult group decreased significantly when compared to the young adult group, and physiological indices such as FVC, FEV1 and FEV 1 /FVC ratio in the elderly adult group showed stronger decreases than in the young adult group or middle-aged adult group. Aging is related to a progressive decline of lung function [17], and subjects with severe persistent asthma were much older than those with mild asthma [18]. Neutrophils were increased in the sputum of elderly asthma subjects. Therefore, neutrophilic airway inflammation is more common in elderly and severe asthma subjects $[19,20]$. In our study, neutrophils in serum and BALF of asthmatic subjects were elevated when compared to normal subjects (Table 1). In the elderly adult group, neutrophils in serum and BALF were elevated as compared to the young adult and middle-aged adult groups, although this difference was not significant (data not shown). Accordingly, the relationship between neutrophils and aging after sub-classification should be analyzed further according to severity.

It is becoming recognized that the immune system declines with age via a process known as immunosenescence, which leads to a higher incidence of infections, 
neoplasia and autoimmune diseases [21]. The agedependent decline in the immune system could be attributed to the functional activity of hematopoietic stem cells in older subjects [22]. Previous studies have reported that total serum IgE in the elderly adult group is lower than in the younger group and total IgE and allergen specific IgE have decreased with age in allergic patients as well as healthy members of the population [23]. In the present study, the level of total IgE in the elderly adult group was decreased relative to the young adult and middle-aged adult groups. However, this difference did not achieve statistical significance (data not shown). As shown in Table 3, Der p 1-specific IgE(class) was decreased in the middle-aged adult and the elderly adult groups relative to the young adult group. More than 31 allergens in the HDMs extracts have been reported to date, and specific IgE reactivity profiles to purified allergens vary in subjects from different countries [24]. Future investigations will need to be conducted to examine the association of other specific-IgEs with aging.

Although we could not detect statistically significant differences in serum TARC between normal subjects and asthmatic subjects, serum TARC was elevated in the elderly adult group relative to the young adult and the middle-aged adult groups, in which serum TARC was not detected (Table 3). Moreover, TARC was positively related to total IgE (Table 4). TARC plays a dominant role in $\mathrm{Th}_{2}$-type disease conditions by recruiting $\mathrm{Th}_{2}$ cells into inflammatory sites [25]. Several studies have demonstrated that there were elevated levels of TARC in patients with atopic dermatitis $[26,27]$ and asthma $[28,29]$. The elevated TARC in asthma patients may be a reflection of increased TARC expression at inflammatory sites of the asthmatic airway [30]. The normal levels of serum TARC in healthy children and adults differ depending on age, with TARC levels being higher in children [31, 32].

However, in our study, the level only increased in the elderly adult group of the asthmatic subjects. It should be noted that this study had a few limitations. First, the asthmatic subjects included in this study show various allergic status (GINA 1-4). The relationship between severity and other parameters cannot be evaluated in this study. Second, we do not have any information regarding whether asthma found in elderly adult groups developed as a result of late onset asthma or was diagnosed in their childhood. Further study will be need to investigate these limitations.

\section{Conclusion}

TARC in serum of the elderly adult group was increased when compared to members of other younger groups, and was positively related to total $\operatorname{IgE}$ in the total and elderly adult asthma group. Cytokines such as IL-6, IL-8, MCP-1, RANTES, and MIP- $1 \alpha$ were significantly altered in the elderly adult group. The results presented herein will help elucidate the pathogenesis of allergic diseases such as asthma, as well as to mining of biomarkers associated with age.

\section{Additional file}

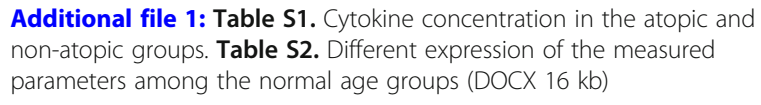

Additional file 1: Table S1. Cytokine concentration in the atopic and non-atopic groups. Table S2. Different expression of the measured parameters among the normal age groups (DOCX $16 \mathrm{~kb}$ )

\begin{abstract}
Abbreviations
BALF: Bronchoalveolar lavage fluid; BSA: Bovine serum albumin;

DF: Dermatophagoides farina; DP: Dermatophagoides pteronissinus;

ELISA: Enzyme linked immunosorbent assay; FEV1: Forced expiratory capacity

in $1 \mathrm{~s}$; FVC: Forced vital capacity; HDMs: House dust mites; MCP: Monocyte

chemoattractant protein; PAR: Proteinase activated receptor; PBS: Phosphate buffered saline; TARC: Thymus and activation regulated chemokine; TLR: Toll like receptor
\end{abstract}

\section{Acknowledgments}

We thank normal volunteers and allergic patients to participate in this study.

\section{Funding}

This work was supported by the BK21 plus program through the National Research Foundation(NRF) funded by the Ministry of Education of Korea.

\section{Availability of data and materials}

Data sharing is not applicable to the present article as no datasets were generated or analyzed while the current study was still going.

\section{Authors' contributions \\ KMJ, HKL, and JWS conducted the experiments and the statistical analyses, $\mathrm{EC}, \mathrm{MHH}$ and $\mathrm{YK}$ helped conducting the experiments with patients and performing immunoassays, ISK designed, supervised the project and the data analysis. All authors read and approved the final manuscript.}

\section{Ethics approval and consent to participate}

This study was approved by the Institutional Review Board of Eulji University for normal volunteers and by the Institutional Review Board of Konyang University for asthma patients (Approval Number EU12-05 and KYUH 08-44). All participants in this study gave their written informed consent. All procedures performed in studies involving human participants were in accordance with the ethical standards of the institutional and/or national research committee and with the Helsinki declaration and its later amendments or comparable ethical standards. Informed consent was obtained from all individual participants included in the study.

\section{Competing interests}

The authors declare that they have no competing interests.

\section{Publisher's Note}

Springer Nature remains neutral with regard to jurisdictional claims in published maps and institutional affiliations.

\section{Author details}

${ }^{1}$ Department of Senior Healthcare, BK21 plus program, Graduate School, Eulji University, Daejeon 34824, Korea. ${ }^{2}$ Department of Biomedical Laboratory Science, School of Medicine, Eulji University, 77, Gyeryoung-ro 771 beon-gil, Jung-Gu, Daejeon 34824, Republic of Korea. ${ }^{3}$ Department of Biomedical Laboratory Science, College of Health Science, Eulji University, Seongnam 13135, Korea. ${ }^{4}$ Department of Respiratory Internal Medicine, College of Medicine, Konyang University, Daejeon 35365, Korea. ${ }^{5}$ Department of Clinical Laboratory Science, Wonkwang Health Science University, Iksan 54538, Republic of Korea. 
Received: 28 September 2017 Accepted: 27 April 2018

Published online: 05 May 2018

\section{References}

1. Holgate ST. Pathogenesis of asthma. Clin Exp Allergy. 2008;38:872-97.

2. Gaffin JM, Phipatanakul W. The role of indoor allergens in the development of asthma. Curr Opin Allergy Clin Immunol. 2009;9:128-35.

3. Jacquet $A$. The role of innate immunity activation in house dust mite allergy. Trends Mol Med. 2011;17:604-11.

4. Kim DH, Choi E, Lee JS, et al. House dust mite allergen regulates constitutive apoptosis of normal and asthmatic neutrophils via toll-like receptor 4. PLoS One. 2015;10:e0125983.

5. Lee NR, Baek SY, Gu A, et al. House dust mite allergen suppresses neutrophil apoptosis by cytokine release via PAR2 in normal and allergic lymphocytes. Immunol Res. 2016;64:123-32.

6. Hammad H, Chieppa M, Perros F, et al. House dust mite allergen induces asthma via toll-like receptor 4 triggering of airway structural cells. Nat Med. 2009;15:410-6.

7. Xia S, Zhang $X$, Zheng $S$, et al. An update on inflamm-aging: mechanisms, prevention, and treatment. J Immunol Res. 2016;2016:8426874.

8. Zuo L, Pannell BK, Liu Z. Characterization and redox mechanism of asthma in the elderly. Oncotarget. 2016;7:25010-21.

9. Ventura MT, Scichilone N, Paganelli R, et al. Allergic diseases in the elderly: biological characteristics and main immunological and non-immunological mechanisms. Clin Mol Allergy. 2017;15:2.

10. Ahmad A, Obaidi AH, Mohamed A, et al. The predictive value of IgE as biomarker in asthma. J Asthma. 2008;45:654-63.

11. Jeong KY, Park JW, Hong CS. House dust mite allergy in Korea: the most important inhalant allergen in current and future. Allergy asthma. Immunol Res. 2012:4:313-25.

12. Arlian LG, Platts-Mills TA. The biology of dust mites and the remediation of mite allergens in allergic disease. J Allergy Clin Immunol. 2001;107:S406-13.

13. Abd Ella OH, Badawy EAM, Shahat $\mathrm{M}$, et al. Allergy to Dermatophagoides pteronyssinus (Der p1) and Dermatophagoides farina (Der f1) in patients with atopic asthma. Int J Sci Res. 2015;4:1896-902.

14. Hosoki K, Ying S, Corrigan C, et al. Analysis of a panel of 48 cytokines in BAL fluids specifically identifies IL-8 levels as the only cytokine that distinguishes controlled asthma from uncontrolled asthma, and correlates inversely with FEV ${ }_{1}$. PLoS One. 2015;10:e0126035.

15. Kuo PL, Hsu YL, Huang MS, et al. Bronchial epithelium-derived IL-8 and RANTES increased bronchial smooth muscle cell migration and proliferation by Kruppel-like factor 5 in areca nut-mediated airway remodeling. Toxicol Sci. 2011;121:177-90.

16. Rossi A, Ganassini A, Tantucci C, et al. Aging and the respiratory system. Aging Clin Exp Res. 1996;8:143-61.

17. Mathur SK. Allergy and asthma in the elderly. Semin Respir Crit Care Med. 2010;31:587-95.

18. Jatakanon A, Uasuf C, Maziak W, et al. Neutrophilic inflammation in severe persistent asthma. Am J Respir Crit Care Med. 1999;160:1532-9.

19. Thomas RA, Green RH, Brightling $\mathrm{CE}$, et al. Influence of age on induced sputum differential cell counts in normal subjects. Chest. 2004;126:1811-4.

20. Mathur SK, Schwantes EA, Jarjour NN, et al. Age-related changes in eosinophil function in human subjects. Chest. 2008;133:412-9.

21. Pawelec G. Immunosenescence: impact in the young as well as the old? Mech Ageing Dev. 1999;108(1):1-7.

22. Aw D, Silva $A B$, Palmer DB. Immunosenescence: emerging challenges for an ageing population. Immunology. 2007;120:435-46.

23. De Amici M, Ciprandi $G$. The age impact on serum total and allergenspecific IgE. Allergy asthma. Immunol Res. 2013;5:170-4.

24. Weghofer $M$, Thomas WR, Kronqvist $M$, et al. Variability of IgE reactivity profiles among European mite allergic patients. Eur J Clin Investig. 2008;38:959-65.

25. Yoshie O. Immune chemokines and their receptors: the key elements in the genesis, homeostasis and function of the immune system. Springer Semin Immunopathol. 2000;22:371-91.

26. Fujisawa T, Fujisawa R, Kato $Y$, et al. Presence of high contents of thymus and activation-regulated chemokine in platelets and elevated plasma levels of thymus and activation-regulated chemokine and macrophage-derived chemokine in patients with atopic dermatitis. J Allergy Clin Immunol. 2002; 110:139-46.

27. Kakinuma T, Nakamura K, Wakugawa M, et al. Thymus and activationregulated chemokine in atopic dermatitis: serum thymus and activation- regulated chemokine level is closely related with disease activity. J Allergy Clin Immunol. 2001;107:535-41.

28. Leung TF, Wong $\mathrm{CK}$, Chan $\mathrm{H}_{\text {, et }}$ al. Plasma concentration of thymus and activation-regulated chemokine is elevated in childhood asthma. J Allergy Clin Immunol. 2002;110:404-9.

29. Reda SM, Hossny E, El-Fedawy S, El-Deen ME. Plasma concentration of thymus and activation-regulated chemokine in childhood asthma. Egypt J Pediatr Allergy Immunol. 2003;1:86-92.

30. Sekiya T, Yamada H, Yamaguchi M, et al. Increased levels of a TH2-type CC chemokine thymus and activation-regulated chemokine (TARC) in serum and induced sputum of asthmatics. Allergy. 2002;57(2):173-7.

31. Tamaki K, Saeki H, Kadono T, et al. Serum TARC/CCL17 levels as a disease marker of atopic dermatitis. Jap J Dermatol. 2006;116:27-39.

32. Fujisawa $T$, Nagao $M$, Hiraguchi $Y$, et al. Serum measurement of thymus and activation-regulated chemokine/CCL17 in children with atopic dermatitis: elevated normal levels in infancy and age-specific analysis in atopic dermatitis. Pediatr Allergy Immunol. 2009;20:633-41.

\section{Ready to submit your research? Choose BMC and benefit from:}

- fast, convenient online submission

- thorough peer review by experienced researchers in your field

- rapid publication on acceptance

- support for research data, including large and complex data types

- gold Open Access which fosters wider collaboration and increased citations

- maximum visibility for your research: over $100 \mathrm{M}$ website views per year

At BMC, research is always in progress.

Learn more biomedcentral.com/submissions 